\title{
«Монгольский», «урянхайский», «баргинский» вопросы в трудах российского востоковеда Евгения Александровича Белова
}

\author{
Юрий В. Кузьмин \\ Байкальский государственный университет, Российская Федерация, \\ Виктория А. Василенко \\ Всероссийский государственный институт кинематографии им. С. А. Герасимова, \\ Российская Федерация
}

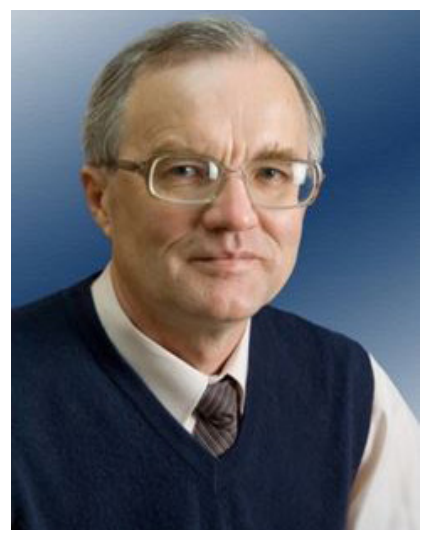

Статья представляет собой историографический анализ ряда работ российского востоковеда Евгения Александровича Белова (1929-2004). Его труды цитируются в большинстве научных работ, посвященных истории взаимоотношений России, Китая, Монголии по «монгольскому», «урянхайскому» и «баргинскому» вопросам. Однако специализированных работ о нем - не было.

Научная ценность работ Е. А. Белова заключается в качественной и глубокой проработке фондов Архива Внешней политики Российской империи, Российского государственного исторического архива, Российского государственного военно-исторического архива и других. Исследователь по-новому рассмотрел вопросы развития панмонгольского движения в регионе, реакции китайской общественности на российскую политику в решении «монгольского вопроса», ликвидации автономии Внешней Монголии в 1919 2.

В настоящей статье рассмотрены отличия оценок Е. А. Белова от существующих подходов к решению спорных проблем, представлено описание его научного вклада в воссоздание исторических сюжетов, имеющих принципиально важное значение для изучения истории дипломатии России, Китая и Монголии начала ХХ в.

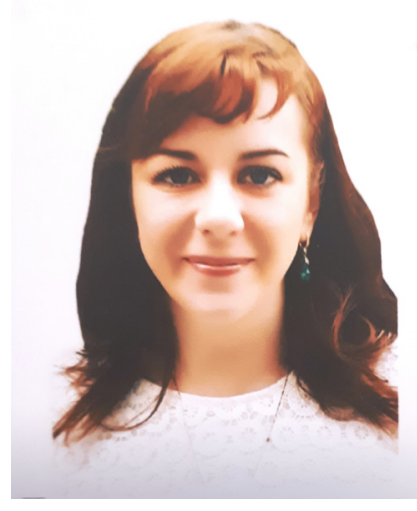

Е. А. Белова можно назвать «первооткрывателем» истории «баргинского вопроса», возникшего после событий 1911 г. В исследовании «урянхайского вопроса» ученый одним из первых рассмотрел вопросы, связанные с пересмотром Чугучакского протокола в конце ХІХ века. Он дал убедительное опровержение точки зрения китайских коллег, акцентирующих внимание на силовом характере установления протектората в Туве.

Ключевые слова: Евгений Александрович Белов; Тува; Монголия; монгольский вопрос; урянхайский вопрос; баргинский вопрос; российская дипломатия; история дипломатии; история тувиноведения; история монголоведения

Статья подготовлена в рамках гранта РФФИ 20-59-4408 «Мировое и российское монголоведение: национальные школы, концепции, персоналии».

Для цитирования:

Кузьмин Ю. В., Василенко В. А. «Монгольский», «урянхайский», «баргинский» вопросы в трудах российского востоковеда Евгения Александровича Белова // Новые исследования Тувы. 2021, № 3. C. 34-48. DOI: https://www.doi. org/10.25178/nit.2021.3.3

Кузьмин Юрий Васильевич - доктор исторических наук, профессор кафедры мировой экономики и экономической безопасности Байкальского государственного университета. Адрес: 664003, Россия, г. Иркутск, ул. Ленина, д. 11. Тел.: +7 (3952) 50-00-05; +7 (924) 548-49-45. Эл. адрес:kuzminuv@yandex.ru

Василенко Виктория Александровна - кандидат исторических наук, научный сотрудник Иркутского филиала Всероссийского государственного института кинематографии им. С. А. Герасимова. Адрес: 664040, Россия, г. Иркутск, ул. Розы Люксембург, д. 170. Тел.: +7 (3952) 44-71-32, +7 (964) 283-30-39. Эл. адрес: vgikinfo3000@yandex.ru

KUZMIN, Yuri Vasilyevich, Doctor of Historical Sciences, Professor of the Department of World Economy and Economic Security, Baikal State University. Postal address: 11 Lenin St., Irkutsk, 664003, Russia. Tel.:+7 (3952) 50-00-05; +7(924) 548-49-45. E-mail: kuzminuv@yandex.ru ORCID ID: 0000-0002-6963-0436 VASILENKO, Victoria Alexandrovna, Candidate of History, Researcher, All-Russian State Institute of Cinematography named after S. A. Gerasimov, Irkutsk Branch. Postal address: 170 Rosa Luxemburg st., Irkutsk, 664040, Russia. Tel.: +7(3952) 44-71-32,+7 (964) 283-30-39. E-mail: vgikinfo3000@yandex.ru ORCID ID: 0000-0002-7273-8026 


\title{
«Mongolian», «Uriankhai» and «Barga» issues in the works of the Russian Orientalist Evgeny Aleksandrovich Belov
}

\author{
Yuri V. Kuzmin \\ Baikal State University, Russian Federation, \\ Viktoria A. Vasilenko \\ All-Russian State Institute of Cinematography named after S. A. Gerasimov, Russian Federation
}

\begin{abstract}
This article is the first historiographical study of the works of the Russian Orientalist Evgeny Aleksandrovich Belov. Most scholars dealing with the history of relations between Russia, China, and Mongolia on the «Mongolian», «Urianhai» and «Barga» issues cite Belov's works - yet there are no dedicated papers to examine his contributions to the field.

Indeed, their real value lies in Belov's in-depth study of the archival materials from the Foreign Policy Archive of the Russian Empire, Russian State Historical Archive, Russian State Military Historical Archive, to name only a few. In a new way, the researcher considered the issues of the development of the pan-Mongolian movement in the region, the reaction of the Chinese public to the Russian policy in solving the «Mongolian question», and the end of Outer Mongolia's autonomy in 1919.

This article examines how Belov's assessments were different from convenient approaches to moot issues. We provide an outline of his contributions to recreating key historical narratives for studying the diplomatic history of Russia, China and Mongolia at the beginning of the 20th century.

Belov can also be seen as the «discoverer» of the history of the «Barga question» that arose after the events of 1911. In his study of the "Uriankhai question», the researcher was one of the first to consider what happened at the revision of the Chuguchak protocol at the end of the 19th century. He gave a convincing refutation of the point of view of his Chinese colleagues, who emphasize the forceful nature of establishing a protectorate over Tuva.
\end{abstract}

Keywords: Evgeny Aleksandrovich Belov; Tuva; Mongolia; "The Mongolian question»; "The Uriankhai question»; "The Barga question»; Russian diplomacy; history of diplomacy; history of Tuvan studies; history of Mongolian studies

Financing:

The article was published within the framework of the RFBR grant 20-59-4408 «World and Russian Mongolian Studies: national schools, concepts, personalities».

For citation:
Kuzmin Yu. V. and Vasilenko V. A. «Mongol'skii», «uriankhaiskii», «barginskii» voprosy v trudakh rossiiskogo vos-
tokoveda Evgeniia Aleksandrovicha Belova [«Mongolian», «Uriankhai» and «Barga» issues in the works of the Russian
Orientalist Evgeny Aleksandrovich Belov]. New Research of Tuva, 2021, no. 3, pp. 34-48. DOI: https://www.doi.
org/10.25178/nit.2021.3.3

\section{Введение}

В подавляющем большинстве современных научных работ, посвященных истории политики и дипломатии стран «центрально-азиатского треугольника» встречаются ссылки, цитирования наиболее известных монографий Евгения Александровича Белова (1929-2004): «Краткая история Синьхайской революции. 1911-1913» (Белов, 2001), «Россия и Китай в начале ХХ века: Русско-китайские противоречия в 1911-1915 гг.» (Белов, 1997), «Россия и Монголия» (Белов, 1999). Е. А. Белов был синологом, специализировался на изучении внутренней и внешней политике Китая, дипломатии России и Китая во второй половине XIX - начале XX в. Однако его научный вклад в изучение вопросов, смежных с историей российско-китайских отношений - «монгольского», «урянхайского», «баргинского», неоспорим. Ученому удалось подробно ввести в научный оборот и проанализировать целый пласт уникальных архивных документов, относящихся к истории дипломатии стран «центрально-азиатского треугольника» начала XX столетия. Работы были изданы в 1990-е гг. - период, когда отечественная историческая наука переживала настоящий «бум». 
Большинство коллег, исследователей согласятся с тем, что вклад Евгения Александровича в изучение истории русско-монгольских и русско-китайских отношений переоценить сложно. Ученому одним из первых удалось ввести в научный оборот документы фондов Российского государственного военноисторического архива (РГВИА), Государственного архива Российской Федерации (ГА РФ), российского государственного исторического архива (РГИА). На основании архивных материалов он переосмыслил существующие оценки, касающиеся решения «монгольского», «урянхайского», «баргинского» вопросов, что было важно для изучения истории внешней политики России, Китая, Монголии начала ХХ века.

Е. А. Белов был одним из первых, кто в постсоветский период стал изучать политику России и Китая в Западной Монголии и Барге1911-1915 гг., панмонголькое движение 1911-1915 гг., антикитайское восстание Удая, ввод войск из Внешней Монголии (Халхи) во Внутреннюю в начале 1914 г., антирусское движение в Китае в связи с подписанием русско-монгольского соглашения 1912г., антикитайское восстание под руководством Бобудчжаба 1915-1916 гг.

В настоящей статье авторы рассматривают представление только трех вопросов - «монгольского» (1911-1919), «баргинского» и «урянхайского» - в трудах ученого. Полный анализ научного вклада Е. А. Белова в изучение политических событий в Западной Монголии требует большего объема, чем одной статьи.

\section{Условия развития научного творчества Е. А. Белова}

Работа Евгения Александровича над основными монографиями, ставшими признанной классикой современного китаеведения, монголоведения, тувиноведения (Белов, 1997, 1999) пришлась, как мы уже упомянули, на девяностые годы. Отечественное востоковедение и историческая наука того периода развивались под воздействием следующих обстоятельств: распада Советского Союза, отказа от марксистко-ленинского подхода в научных исследованиях, открытия ранее закрытых фондов федеральных и региональных архивов.

Многие государства, в которых изменились условия общественно-политической жизни, находились в поиске новых форматов взаимодействия с сопредельными странами. Для Монголии демократическая революция и распад Советского Союза стали важными факторами, побудившими руководство страны к изменению ряда доктринальных установок при определении направлений внутренней и внешней политики. В свою очередь, на этапе укрепления общероссийской государственности особую значимость приобрели вопросы сохранения целостности границ. Актуализация пограничных вопросов в истории приобрела особый смысл. Появилось большое количество работ, в которых с новых позиций и под иным углом зрения рассматривались спорные моменты в истории стран Центральной Азии.

«Развенчание» марксистко-ленинского подхода обусловило появление новых оценок, методологических подходов в исторических исследованиях. В это время получила признание концепция «многофакторного равновесия» А. Д. Воскресенского в изучении истории Китая (Воскресенский, 1997). Впервые был применен метод стратагем в ряде исследований В. С. Мясникова (Мясников, 1997, 2002), набирали популярность подходы, используемые в политологии (концепции «баланса», «дисбаланса», взаимодействия «малых и «больших» региональных систем и проч.) (Лузянин, 1996, 1997).

В это время выходят в свет сборник документов «Русско-монгольские отношения 1636-1654 гг.» (Слесарчук, 1996), а также сборник документов фондов российских государственных и ведомственных архивов, ранее недоступных исследователям (За три века ..., 1995). Были опубликованы обобщающие работы, посвященные отечественному и национальному монголоведению (Российские монголоведы ..., 1997; История отечественного ..., 1997; Улымжиев, 1997), издан библиографический словарь С. Д. Милибанд, посвященный отечественным востоковедам (Библиографический словарь ..., 1995).

С начала 1990-х годов уже в постсоветском пространстве продолжается активное сотрудничество мирового сообщества ученых-востоковедов. На VI Международном конгрессе монголоведов, состоявшемся в 1992 г., впервые были представлены иные оценки о характере политики российских властей, действий российской дипломатии в решении «монгольского» и «урянхайского» вопросов. Появляются новые работы Б. П. Гуревича (Гуревич, 1992), М. И. Гольмана (Гольман, 1998), В. В. Грайворонского (Грайворонский, 1996), С. К. Рощина (Политическая история ..., 1999) и других именитых исследователей, в которых впервые зазвучали идеи не только о негативном, но и позитивном влиянии Российской империи на решение указанных спорных вопросов. На международных научных конференциях также 
были представлены новые точки зрения по вопросам отношений стран «центрально-азиатского треугольника», с позиций новых методологических подходов, отличных от марксистко-ленинской идеологии (Белов, 1992, 1994а; Дацышен, 1996).

В регионах России также сохранился интерес к актуальным проблемам востоковедения и монголоведения. В 1997 г. в Улан-Удэ был создан Институт монголоведения, буддологии и тибетологии СО РАН на базе Бурятского института общественных наук СО РАН. Сотрудники Тувинского научно-исследовательского института языка, литературы и истории продолжали исследования в различных областях гуманитарных наук, смежных с востоковедением (Ученые записки, 1995: 30-62). На базе иркутских университетов проводится серия международных научных конференций «Россия и Восток: взгляд из Сибири» (Россия и Восток ..., 1998). В этот же время проходит защита докторских диссертаций по актуальным проблемам монголоведения и востоковедения (Кузьмин, 1998; Лиштованный, 1998; Лузянин, 1997).

Описываемый период был также очень насыщенным в жизни Евгения Александровича Белова, наполненным как радостными моментами, так и по-настоящему трагичными.

В справочнике С.Д. Милибанд «Библиографический словарь отечественных востоковедов с 1917 г.» значится очень лаконичная информация о Евгение Александровиче (Библиографи-

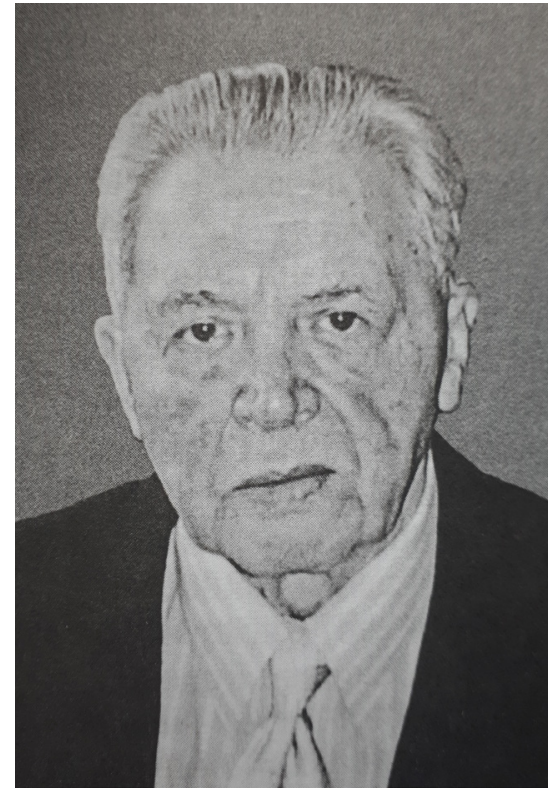

Фото 1. Белов Евгений Александрович (1929-2004)1.

Photo 1. Evgeny Aleksandrovich Belov (1929-2004). ческий словарь ..., 1995: 146).

Родился Евгений Александрович Белов² 16.11.1929 г. в деревне Турищево Западной (Смоленской) области в крестьянской семье. В послевоенное время переехал в Москву, в 1953 г. закончил исторический факультет МГУ, перешел на работу в качестве научного сотрудника Института востоковедения в 1956 г.

В 1957 г. защитил кандидатскую диссертацию по теме: «Революция 1911-1913 гг. в Китае» (Белов, 1956). В 1994 г. стал доктором наук. После защиты докторской диссертации «Русско-китайские отношения в 1911-1915 гг.» (Белов, 1993b). До последних дней жизни работал в отделе истории Китая (ныне - Отдел Китая) Института востоковедения Российской Академии наук.

К сожалению, биография и творчество Е. А. Белова больше не нашли отражения в иных справочных изданиях.

\section{Евгений Александрович Белов: ученый и личность}

Каким был Евгений Александрович? Наверное, о его характере и заслугах перед отечественным востоковедением лучше скажут близкие друзья и коллеги. Не будет преувеличением сказать, что его поддержка, личные консультации для большинства исследователей, занимающихся вопросами политической истории Китая, Монголии и «центрально-азиатского треугольника» имели большую ценность. Авторам статьи также посчастливилось лично познакомиться и недолго общаться с ним.

Знакомство первого автора статьи с Евгением Александровичем состоялось в 1992 г., за год до его защиты докторской диссертации. Впечатлило полное погружение Е. Белова в тему, он буквально жил ею. Говорил о том, что было важно для него: стремлении как можно полнее охватить исследуемый период, ввести значительное число оригинальных архивных документов в работу. Его интересовали буквально все детали переписки консулов в Урге, Кобдо, российского посланника в Пекине с вышестоящим руководством, представителями китайского и монгольского правительств. Безусловно, внимание ученого занимали материалы иркутских и других сибирских архивов по указанной теме. Осталось также впечатление о чувстве творческого одиночества ученого, отсутствие у коллег интереса к теме его исследования.

\footnotetext{
${ }^{1}$ Фото из антологии «Урянхай. Тыва Дептер» (Урянхай. Тыва ..., 2007: 496).

${ }^{2} \mathrm{~K}$ сожалению, не знающие ученого могут спутать его с другим историком, полным тезкой, специалистом по истории Руси, мемуаристом Е. А. Беловым (https://dic.academic.ru/dic.nsf/enc_biography/9502/белов), что также вызывает необходимость восстановления биографии Е. А. Белова востоковеда.
} 
Другая автор статьи познакомилась с Е. А. Беловым в период обучения в аспирантуре Иркутского государственного педагогического университета ${ }^{1}$ в 2004 г. Ее опыт научно-исследовательской работы был еще небольшим, поэтому впечатление от знакомства с научной эрудицией ученого было неизгладимым.

Евгений Александрович в общении был на редкость простым, дружелюбным, открытым и добрым человеком. Он предоставил возможность лично ознакомиться со сделанными им некоторыми выписками из архивов. Несколько своих книг (Белов, 1999, 2001, 2003), Евгений Александрович любезно подарил. Много говорил о научных проблемах, которые его интересовали наиболее всего: о роли барона Унгерна в развитии панмонгольского движения, решении «баргинского вопроса» в начале XX в. По материалам его монографии об Унгерне планировалось тогда снять документальный фильм в Италии, о чем Евгений Александрович подробно и увлеченно рассказывалㄹ․ Делился воспоминаниями о Китае, первой и единственной в поездке в страну, историей которой занимался всю жизнь.

Е. А. Белов

\section{Россия и Китай} в начале XX века

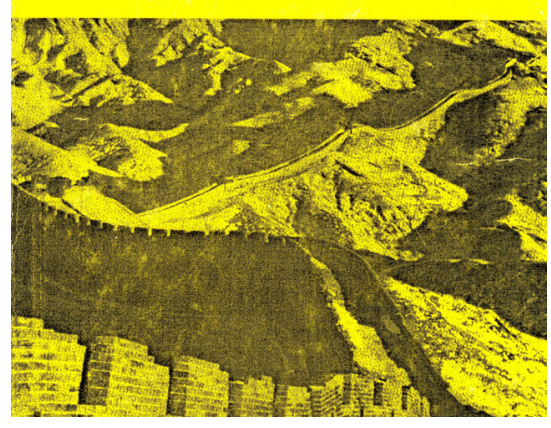

Фото 2. Обложка монографии Е. А. Белова «Россия и Китай в начале XХ века (русско-китайские противоречия в 1911-1915 22.)». М.: ИВ РАН, 1997. Photo 2. The cover of E. A. Belov's book

"Russia and China at the beginning of the 20th century: Russian-Chinese contradictions, 1911-1915” Moscow, IV RAN, 1997.

Говорили не только о работе, но и на житейские темы. Поразили его оптимизм, жизнелюбие. Чтобы не случилось, говорил он, нужно радоваться жизни и обязательно любить то, что ты делаешь. Очень тепло было на душе от таких встреч. Было очевидно, что в людях Евгений Александрович ценил искренность и уважение к науке и знаниям. С особой теплотой говорил о коллегах, с которыми был знаком лично: А. Ч. Бомбужай, В. Г. Дацышене, Ю. Ч. Хомушку и других исследователях.

Много рассказывал о сборе материалов в архивах. Работа велась, по воспоминаниям Е. А. Белова, в жестком режиме. Например, в Государственном историческом архиве (РГИА) автор работал дни напролет, в «бешеном», по его словам, темпе. Кроме того, обработка архивных документов и написание его основных работ по истории Китая и Монголии для Евгения Александровича совпали со сложнейшим периодом в жизни в начале 2000-х гг. Болезнь супруги и ее смерть, гибель младшей дочери в автомобильной аварии стали для него страшным испытанием. Но все же материал был собран и опубликован, работы получили заслуженное признание синологов, монголоведов всего мира (Белов, 1997, 1999, 2001) (фото 2 и 3).

Он очень хотел издать документы Архива Внешней политики Российской империи (АВПРИ), планировал даже их опубликовать в совокупности с материалами сибирских архивов. На прощание договорились переписываться и работать над сборником документов. Расстались как будто ненадолго, но в скором времени узнали печальную новость: в мае 2004 г. Евгения Александровича не стало.

Замечательный человек, ученый ушел из жизни, что называется, «на бегу»: осталось много необработанных архивных материалов, планов, творческих замыслов. Так, наверное, и должно быть у талантливых исследователей...

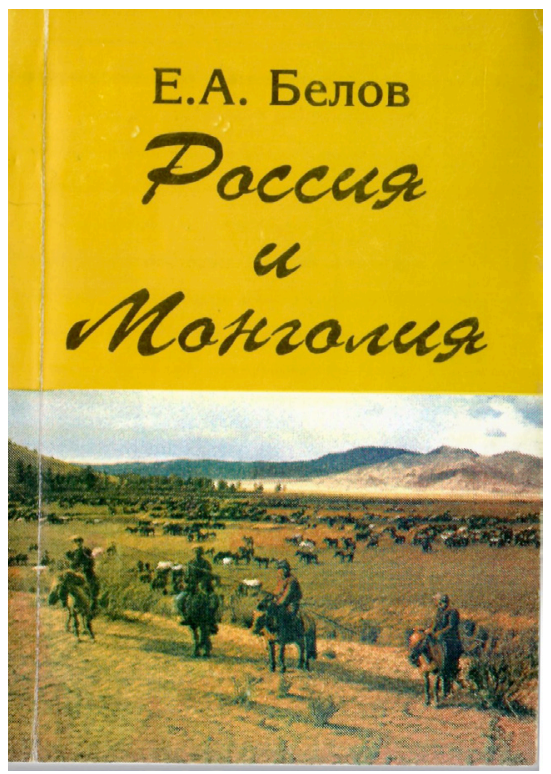

Фото 3. Обложка монографии Е. А. Белова «Россия и Монголия (1911-1919)». М.: ИВ РАН, 1999.

Photo 3. The cover of E.A. Belov's book "Russia and Mongolia, 1911-1919”. Moscow, IV RAN, 1999.

\footnotetext{
${ }^{1}$ В настоящий момент это структурное подразделение Иркутского государственного университета (Педагогический институт ИГУ).

${ }^{2}$ Хатунцев С. В. Современная «Унгерниана» [Электронный ресурс] // CЛOBO. Образовательный портал. URL: https://www.portal-slovo.ru/history/41083.php (дата обращения 02.07.2021).
} 


\section{«Монгольский вопрос» в трудах Е. А. Белова}

В конце 1990-х годов основные доктринальные установки в истории международных отношений в Центральной Азии сменились не только в России. Хронологически близкими работам Евгения Александровича были работы монгольского историка Б. Лхамсурэна «Внешняя среда и государственная независимость Монголии» (Лхамсурэн, 1995). Автор рассматривал провозглашение независимости Монголии в 1911 г. не иначе как «национально-освободительную революцию» (там же: 118). Однако, отмечал Е. А. Белов, речь шла о реализации основной цели халхасского правительства - ликвидации колониальной зависимости от Китая, а не кардинальном изменении общественно-политического строя Внешней Монголии. Следовательно, он придерживался точки зрения, принятой большинством российских историков-монголоведов: в Монголии было развернуто национально-освободительное движение, которое нельзя было назвать революцией в общепринятом смысле слова (Белов, 1999: 6; Гуревич, 1992: 57; Кузьмин, 1995, 1997: 208).

Сам факт провозглашения независимости в Монголии в 1911 г. ученый связывает со следующими факторами: 1) националистической деятельностью халхасской элиты; 2) поддержкой светских и ду ховных феодалов, оказанной правительству Джебзун-Дамба Хутухты; 3) отказом китайских солдат защищать маньчжуров (Белов, 1999: 52-55). Процесс подготовки соглашения России и Монголии 1912 г., последующие переговоры о политическом статусе Халхи, подписание соглашения в Кяхте были детально описаны ученым в ряде работ (Белов, 1994b: 178-181; 1999, 2007).

Наибольшую научную ценность представляет изучение Е. А. Беловым «подготовительного» этапа российско-китайских и российско-монгольских переговоров, предваряющего подписание декларации 1913 г. и Кяхтинского соглашения 1915 г. Ученый скрупулезно обработал переписку управляющего российским консульством в Урге В. Н. Лавдовского с министерством иностранных дел, рапорты чрезвычайных посланников в Пекине И. Я. Коростовца и В. Н. Крупенского. Также он провел подробный анализ содержания переписки с Министерством иностранных дел Китая. В его работах дано развернутое описание содержания переписки товарища министра иностранных дел А. А. Нератова с И. Я. Коростовцом, после назначения последнего главой дипмиссии в Ургу (Белов, 1997: 153-177; 1999 : 36-133).

Одной из важных заслуг ученого было опровержение тезиса о том, что переводы текстов российско-монгольского соглашения 1912 г. отличались. Как известно, это соглашение было взято за основу декларации 1913 г. По мнению авторов коллективной монографии «История Монгольской народной республики» (История Монгольской..., 1967), в монгольском варианте российско-монгольского соглашения относительно определения политического статуса использовалась формулировка «полная независимость», а в российском варианте - «автономия» (там же: 241-242). Е. А. Белов, ссылаясь на материалы фонда «Трактаты» Архива внешней политики Российской Империи, доказал, что тексты были идентичными. С этой позицией ученого были солидарны монгольские и российские коллеги (Шурхуу, 2001: 97-102; Мясников, 1997: 113-117, Кузьмин, 1997, 1998). Действительно, ни в переписке министра иностранных дел Сазонова с П. Я. Коростовцом, ни в статье 4 русско-монгольского соглашения никогда не упоминалось о «расхождении текстов» монгольского и российского вариантов соглашений (Белов, 1994b: 173-176).

Одним из первых ученый, опираясь на документы архивов, проанализировал второй этап переговоров России и Китая второй половины 1912 г., в котором активное участие приняла Монголия. Исследователь привел подробное описание переписки И. Я. Коростовца с членами правительства Внешней Монголии (там же: 178-180; 1999: 105-118), что позволило выявить ряд дополнительных обстоятельств.

Активность монгольских министров, их вмешательство в ход переговоров России и Китая о политическом статусе Халхи были немаловажным фактором, способствовавшим принятию решения о предоставлении прав широкой автономии в составе Китая (там же: 181).

Также одним из первых он опубликовал сводки российских и китайских газет, освещающих вопрос о приезде монгольской делегации в Петроград для обсуждения вопроса о покровительстве России: «Русское слово», «Гоминь гунбао», «Сяньбао» (Белов, 1994b: 176-178). Активность монгольских чиновников свидетельствовала о том, что Халха Монголия заявила о себе как о самостоятельном субъекте международной политики, способном находить нужный баланс при решении важных вопросов с более могущественными державами. 
На основании проанализированных документов фонда «Китайский стол» АВПРИ Е. А. Белов ввел в научный оборот материалы сводок газет за 1912 г., в том числе, информационного агентства «Рейтер», освещавших решение «монгольского вопроса» в политике России, Китая, Монголии (Белов, 1999: 88).

Проводя анализ событий 1911-1919 гг., имеющих историческое значение для России, Китая, Монголии, ученый оценил роль отдельных исторических деятелей. Он дал характеристику Да-ламе Цэрэн Чимиду, активному стороннику развития панмонгольского движения и присоединения Барги к Халхе. Пристальное внимание исследователь уделял противоречиям, существующим между Да-ламой и российским правительством, в особенности, с генконсулом в Урге В. Ф. Любой (Белов, 1992).

В судьбоносные моменты истории нередко имеет большое значение личностный фактор. Так, Е. А. Белов одну из своих статей посвятил личности Богдо-хана (Белов, 1996). В монографии «Россия и Монголия», опираясь на материалы фондов Российского государственного военно-исторического архива, он приводит характеристику действий наместника Цинов в Урге, амбаня Сань До, представленную начальником русского конвоя Аветисовым: «Будь на месте Сань До человек смелый и решительный, безусловно, здесь никакого переворота не могло быть. ... Смешно сказать, БогдоГеген и князья, объявляя независимость Монголии и предлагая амбаню Сань До с его чиновниками и гарнизоном удалиться из Урги и Монголии, не имели за собою ни одного патрона для поддержания этого своего требования» (Белов, 1999: 49).

Впервые в рамках изучения «монгольского вопроса» в российской историографии Е. А. Белов дал описание реакции китайской общественности на российско-монгольское соглашение 1912 г. Ученый ввел в научный оборот переведенные с китайского на русский язык сведения из китайских газет «Чжунго Бао», «Миньшибао», «Аньябао» и проч. (Белов, 1994а), что имеет для монголоведения несомненную ценность.

После того, как стало известно содержание российско-монгольского соглашения 1912 г., в Китае против него в 1913 г. было развернуто масштабное движение, принявшее выраженный антирусский характер. Е. А. Белов впервые в отечественной историографии привел факты об участии в движении ведущих партий Китая, военных губернаторов (дуду), наместника Маньчжурии Чжана Силуаня. Иследователь подробно описал деятельность «Общества спасения Монголии», женских патриотических обществ в Пекине и Шэнси, формировавших военные отряды для похода в Монголию; довольно подробно представил описание бойкотирования русских товаров китайскими купцами, деятельность отделений Русско-Азиатского банка ${ }^{1}$ (там же:112-114).

В целом, в отличие от советских и китайских историков (Златкин, 1957; 沙俄侵略中国的 史, 1986), общий характер переговоров 1911-1912 гг. России, Китая и Монголии Е. А. Белов оценивал положительно. Что касается заключения Кяхтинского соглашения 1915 г., то оно также получило позитивную оценку ученым. В монографии «Россия и Монголия» автор писал, что «Кяхтинское соглашение фактически закрепляло первый крупный шаг на пути Внешней Монголии к достижению своей независимости, созданию самостоятельного государства, хотя этот путь был еще сложен и относительно долог» (Белов, 1999: 128).

Данную точку зрения на предмет заключения Кяхтинского соглашения разделяли также большинство историков, чьи работы хронологически совпадали с исследованиями Е. А. Белова (Даревская, 1994; Единархова, 1996; Кузьмин, 1995, 1996, 1997; Лузянин, 1997).

Особое внимание Евгений Александрович уделял вопросам ликвидации автономии Внешней Монголии в 1919 г., развития панмонгольского движения 1919 г. Ученый выделил следующие причины ликвидации монгольской автономии: переход влиятельных чиновников Халхина сторону Китая, присутствие в Урге вооруженных китайских формирований (4 тыс. чел.), слабость позиций Омского правительства, которое уже начало терпеть поражения от Красной Армии, слабость вооруженной защиты Джебзун-дамба Хутухты (Белов, 1999: 168-191).

Таким образом, Е. А. Белов впервые в российской историографии в научный оборот ввел полный комплекс архивных документов АВПРИ по «монгольскому вопросу», представил сложную картину русско-монгольских отношений начала XX в., подробно проанализировал механизм принятия в России внешнеполитических решений в указанном направлении.

\footnotetext{
${ }^{1}$ Антирусское движение в стране было остановлено в 1913 г. Юанем Шикаем, президентом Первой Китайской республики (1912-1916).
} 


\section{«Баргинский вопрос» в трудах Е. А. Белова}

Барга ${ }^{1}$ входила в состав Цинской империи. После объявления независимости Халхи в 1911 г. этот регион, наряду с Западной Монголией и Танну-Урянхаем, должен был стать частью «Великой Монголии». В отечественной литературе XX столетия «баргинский вопрос» был кратко рассмотрен в работах Г. Е. Грумм-Гржимайло (Грумм-Гржимайло, 1926), И. Я. Златкина (Златкин, 1957), в коллективной монографии китайских ученых «История агрессии царской России в Китае» (沙俄侵略中国的 史, 1986). Однако подробного освещения в научной литературе того периода он не получил. Исключение составляют работы более позднего периода (Тарасов, 2013; Дацышен, 2014; Кузьмин, 2019). Ранее, до публикаций работ Е. А. Белова, «баргинский вопрос» упоминался в связи с событиями более позднего периода 1919 г. (движение атамана Семенова, деятельность барона Унгерна в Монголии) (ГруммГржимайло, 1926). Однако проблема решения означенного вопроса в русско-китайской и русскомонгольской дипломатии в 1912 г. историками, фактически, не изучалась.

Барга была первым регионом, который откликнулся на призыв Джебзун-дамба Хутухты о создании «Великой Монголии». В январе 1912 г. она объявила о своей независимости от Китая, а в мае присоединилась к Халхе. В работах Е. А. Белова впервые в отечественной историографии был показан анализ действий царского правительства в отношении Барги, введена в научный оборот переписка посланника в Пекине В. Н. Крупенского с китайским правительством, что позволило создать более полную историческую картину. После присоединения Барги к Внешней Монголии область получила фактически привилегированный статус: баргуты не уплачивали налогов в казну Урги и имели лишь обязательство предоставлять новобранцев для службы в составе монгольского войска. С этого времени наблюдается рост экономических интересов российских купцов и промышленников в Барге: начинается активная аренда земельных участков у баргутов русскими, ловля рыбы (было создано 22 рыбных концессии), была организована добыча золота, каменного угля и соли (Белов, 1993а: 175).

Указанные обстоятельства стали важным фактором, оказавшим влияние на позицию С. Д. Сазонова ${ }^{2}$ в «баргинском вопросе». К числу основных требований, выдвигаемых российской дипломатией Китайскому правительству, относились утверждение всех коммерческих сделок русских торговцев и промышленников, предоставление права постройки подъездных путей к КВЖД и т. д. Перечень требований о территориальном и политическом статусе Барги, выдвигаемых российскими, а затем и баргутскими властями 1912-1915 гг., также был впервые представлен в российской историографии Е. А. Беловым.

В последующий период времени российское министерство иностранных дел не спешило оперативно решить «баргинский вопрос». Этот факт ученый объяснял комплексом причин. К их числу следовало отнести отсутствие согласованных действий царской дипломатии и военных, о чем неоднократно повторял С. Д. Сазонов (там же: 177), стремление получить железнодорожные концессии на постройку железных дорог в Маньчжурии. Сазонов рассчитывал на то, что Северная Маньчжурия присоединится к России, и присоединение Барги к Халхе было нежелательным (там же: 175).

Соглашение о Барге было подписано только в 1915 г. Несмотря на откровенное навязывание Россией собственных условий Китайскому правительству, оно имело, по словам ученого, для баргутов особую ценность, выражавшуюся в получение фактической независимости от Пекина (там же: 176).

Итак, впервые в мировой историографии на основе оригинальных материалов Е. А. Белов наиболее полно представил позицию России по «баргинскому вопросу», показал сложность этой проблемы в русско-монголо-китайских отношениях и противоречивость российской позиции, выражавшуюся в непоследовательности принятия решений.

\section{«Урянхайский вопрос» в трудах Е. А. Белова}

В 1990-е годы в России появляется большое количество работ, в которых «урянхайский вопрос» получил рассмотрение в качестве обязательной составляющей внешней политики, дипломатии сопредельных государств конца XIX - начала XX веков (Кузьмин, 1998; Лузянин, 1997; Дацышен, 2000). Работы Е. А. Белова, рассматривающие данную проблематику, были опубликованы в журналах

\footnotetext{
${ }^{1}$ Барга (Хулуньбуир) - область, расположенная во Внутренней Монголии. В настоящее время на территории Барги располагается три хошуна: Чэнь-Барга Ци, Шинэ-Барга-Юци, Шинэ-Барга Цзоци.

${ }^{2}$ Сазонов Сергей Дмитриевич (1860-1927) - министр иностранных дел Российской империи в период с 8 ноября 1910 г. по 7 июля 1916 г.
} 
«Восток» «Отечественная история» (Белов, 1995, 2007). Отдельные главы, посвященные «урянхайскому вопросу», представлены в монографиях «Россия и Китай», «Россия и Монголия» (Белов, 1997, 1999).

Эта часть работы ученого получила довольно подробное рассмотрение в отечественной и зарубежной историографии (Батсайхан, 2011; Кузьмин, 1998; Лузянин, 2000; Шурхуу, 2001; Дацышен, 2014; Василенко, 2014).

Научную ценность представляет подробный анализ Е. А. Беловым переписки исполняющего обязанности консула в Улясутае А. П. Хионина с министерством иностранных дел, генерального консула в Урге А. Я. Миллера- с правительством Монголии, переписка военного министра В. А. Сухомлинова и С. Д. Сазонова.

Помимо этого, Е. А. Белов впервые в современной историографии описал несколько сюжетов, предваряющих установление протектората России над Тувой в 1914 г.

Так, он один из первых тщательно изучил так называемый «чапчальский инцидент» (Белов, 1997: 184). Его сущность заключается в обсуждении вопроса русских дипломатов с китайским правительством о совместной проверке пограничных знаков. Особую остроту указанный вопрос приобрел после того, как во время экспедиции полковника В. Л. Попова в Урянхайский край в 1910 г. на перевале Чапчал поручик Августус сжег один из пограничных столбов. В монографии «Россия и Китай в начале XX века» Е. А. Белов в рамках рассматриваемых событий впервые опубликовал переписку П. А. Столыпина с томским губернатором. Она содержала указания иркутскому генерал-губернатору об отлагательстве пересмотра пограничных знаков и восстановлении пограничного столба (там же: 184-185).

Также ученый провел подробный анализ переписки уполномоченного посланника в Пекине И. Я. Коростовца с министерством иностранных дел Китая по вопросу инцидента, произошедшего на Чапчале. Данный прецедент, имеющий частный характер в российско-китайской дипломатии, по существу, свидетельствовал о «поворотной» позиции российского правительства в решении «урянхайского вопроса»: был взят четкий курс на включение края в орбиту политического влияния России ${ }^{1}$.

Одним из первых исследователей Е. А. Белов дал подробное описание переговоров российского и китайского правительств, связанных с пересмотром Пекинского договора 1881 г. в период 1910-1911 гг. (там же: 72-79). На переговорах российское правительство выдвинуло ряд выгодных для себя условий, включая введение права беспошлинной торговли в Синьцзяне и Монголии, открытие российских консульств в Кобдо, Хами, Гучен и проч. В случае неудовлетворения указанных требований российское правительство должно было ввести войска. Местом для их ввода изначально был Усинский округ, граничащий с Урянхаем, однако, по причине его отдаленности, выбор пал на Джаркент, расположенный вблизи Илийского края (там же:76).

Говоря об установлении протектората России над Тувой в 1914 г., ученый подчеркивал, в первую очередь, что само событие носило мирный характер. Тем самым, он дал опровержение точки зрения китайских коллег о силовом характере установления протектората в Урянхае. При этом он ссылался на ряд фактов: на момент установления протектората в край войска не вводились, а назначенный на должность пограничный комиссар А. П. Церерин имел в своем распоряжении только конвой в 10 человек. Сам же вопрос о протекторате решался политическими средствами, дипломатическим маневрированием и давлением России на урянхайцев и монгольское правительство в Туве (там же: 171-198). Факт установления протектората исследователь оценивал положительно, поскольку это стало первым шагом к политическому самоопределению тувинского народа (Белов, 1995).

Характер действий российской дипломатии в период 1911-1917 гг. был обусловлен ходом международных событий на Востоке, где ключевым моментом была Синьхайская революция, а также событиями в самой России. Ситуация изменилась после 1917 г. с установлением режима Временного правительства и приходом к власти большевиков.

Исследователь одним из первых ввел в научный оборот документы, касающиеся политики Временного правительства по «урянхайскому вопросу». Е. А. Белов опубликовал переписку помощника комиссара в Урянхайском крае Я. И. Мальцева с вышестоящим руководством Временного правительства. В статье «Борьба за Урянхайский край в 1915-1919 гг.» исследователь дал характеристику

\footnotetext{
${ }^{1}$ Поворотным моментом «урянхайской политики» России стало заседание Совета Министров 21 ноября 1911г., на котором состоялось обсуждение основных мероприятий по вопросам дальнейшего усиления русского влияния в крае.
} 
событий 1919 г. (Белов, 2007: 515-518). Они были связаны с первыми вооруженными столкновениями объединенных китайско-монгольских отрядов Ян Шичао (специальным комиссаром Китайской республики по китайским делам) и монгольским князем, комиссаром Урянхайского края с монгольской стороны, Итегэмджиту с русскими отрядами дружинников и казаков в конце марта - начале июля 1919 г. При оценке указанных событий Е. А. Белов отмечал, что совместные действия Урги и Пекина, направленные на захват Урянхайского края в 1919 г., были крупной политической ошибкой властей Монголии. Этим, отмечал исследователь, монгольское правительство «отвлекло свои силы, в том числе, и военные, от основной своей задачи - защиты Внешней Монголии от настойчивого стремления Китая ликвидировать ее автономию» (Белов, 1999: 167). По существу, считал ученый, эта ошибка положила начало ликвидации автономии Внешней Монголии (Белов, 2007: 517).

«Урянхайский вопрос» оказался наиболее сложным и запутанным в треугольнике «Россия - Монголия - Китай». Е. А. Белов на основе архивных документов показал сложную систему национальных интересов и противоречий по пограничному вопросу в регионе Центральной Азии.

В дальнейшем его идеи получили свое развитие в публикациях В. Г. Дацышена, Г. А. Ондар, В. А. Василенко, А. К. Бумбажай (Бумбажай, 1999; Дацышен, Ондар, 2003; Василенко, 2014).

\section{Заключение}

Высокая научная ценность работ Е. А. Белова, их значительный вклад в развитие мирового и отечественного востоковедения, китаеведения, монголоведения, неоспоримы.

Огорчает тот факт, что фактически все труды Евгения Александровича изданы небольшими тиражами. В фондах государственных библиотек отсутствуют оцифрованные копии работ ученого. Например, тираж книги «Россия и Монголия» (Белов, 1999) насчитывает всего 300 книг, они стали редкой удачей для их владельцев. У авторов статьи есть экземпляры с дарственной надписью Евгения Александровича.

Переиздание его работ осуществлялось только в отдельных случаях. Например, в пятом томе антологии «Урянхай. Тыва Дептер» переиздана его статья «Борьба за Урянхайский край в 1915-1919 гг.» из журнала «Отечественная история» за 1998 г. (Белов, 2007). Поэтому не будет преувеличением сказать о том, что в настоящее время существует очевидная необходимость переиздания основных трудов Е. А. Белова и восстановления его биографии, как одного из крупнейших отечественных востоковедов.

\section{СПИСОК ЛИТЕРАТУРЫ}

Батсайхан, О. (2011) Монголын сүүлчийн эзэн хаан VIII Богд Жавзандамба [Последний император Монголии VIII Богд Джаузандамба-Хутухта]. Улаанбаатар : Адмон. 708 с. (На монг. яз.)

Белов, Е. А. (1956) Революция 1911-1913 гг. в Китае : дисс. ... к-та ист. н. М. 318 с.

Белов, Е. А. (1992) Дала-лама Цэрэн Чимид и царская дипломатия // VI Международный конгресс монголоведов (Улан-Батор, авг. 1992 г.) / главн. ред. В. М. Солнцев. М. : Ин-т востоковедения. 262 с. С.2-14.

Белов, Е. А. (1993а) Баргинский вопрос по материалам русских архивов // Восток. № 1. С. 170-178.

Белов, Е. А. (1993b) Русско-китайские отношения в 1911-1915 гг. : дисс. ... д-ра ист. н. М. 546 с.

Белов, Е. А. (1994а) Реакция в Китае на русско-монгольское соглашение 1912 г. // Проблемы Дальнего Востока. № 4. С. $108-118$.

Белов, Е. А. (1994b) Как возникли тройственные русско-китайско-монгольские переговоры в Кяхте в 1914 г. // Китайская традиционная культура и проблемы модернизации. Тезисы докладов $\mathrm{V}$ международной научной конференции «Китай. Китайская цивилизация и мир». Москва, 12-14 октября / отв. ред Р. М. Асланов. М. : ИДВ PAH. 184 c. С. $175-181$.

Белов, Е. А. (1995) Проблема Урянхайского края в русско-китайско-монгольских отношениях 1911-1914 гг. // Восток. № 1. С. $58-67$.

Белов, Е. А. (1996) Последний «живой Бог монголов» // Азия и Африка сегодня. № 3. С. 2-17.

Белов, Е. А. (1997) Россия и Китай в начале ХХ века (русско-китайские противоречия в 1911-1915 гг.). М. : ИВ РАН. 314 c.

Белов, Е. А. (1999) Россия и Монголия (1911-1919). М. : ИВ РАН. 235 с.

Белов, Е. А. (2001) Краткая история Синьхайской революции. 1911-1913. М. : Восточная литература РАН. 160 с. 
Белов, Е. А. (2003) Барон Унгерн фон Штернберг: Биография. Идеология. Военные походы. 1920-1921 гг. М. : Аграф. 240 с.

Белов, Е. А. (2007) Борьба за Урянхайский край в 1915-1919 годах // Урянхай. Тыва Дептер. Антология научной и просветительской мысли о древней тувинской земле и её насельниках, об Урянхае - Танну-Туве, урянхайцах тувинцах, о древностях Тувы (II тысячелетие до н.э. - первая половина XX в.) : в 7 т. / сост. С. К. Шойгу. М. : Слово/ Slovo. T. 5.733 с. С. $496-519$.

Библиографический словарь отечественных востоковедов с 1917 года. (1995) : в 2 кн. / сост. С. Д. Милибанд. 2-е изд., перераб. и доп. М. : Наука. Кн. І. А-Л. 702 с.

Бумбажай, А. К. (1999) Россия и Тува: проблема становления связей в конце XIX - начале XX веков : автореф. дисс. ... к. ист. н. М. 28 с.

Василенко, В. А. (2014) На пути к протекторату (отношения правительства имперской России с Китаем и Монголией по вопросам установления политического влияния в Туве во второй половине XIX в. - 1914 г.). Иркутск : Издательство Иркутского государственного университета. 223 с.

Воскресенский, А. Д. (1997) Россия и Китай: теория и история межгосударственных отношений. М. : Моск. Обществ. Научн. фонд. 405 с.

Россия и Восток: взгляд из Сибири (1998): Материалы и тез. докл. к ХІ Междунар. научно-практической конференции. Иркутск, 13-16 мая / редкол.: В. И. Дятлов (отв. ред.) и др. Иркутск : Издательство Иркутского университета. Т. 2. 302 с.

Грайворонский, В. В. (1996) Монголия: изменения в структуре семейных бюджетов сельского населения при переходе от социалистической модели развития к рыночной. М. : Ин-т востоковедения РАН. 64 с.

Гольман, М. И. (1998) Изучение истории Монголии на Западе, XIII - середина XX в. М. : Наука. 218 с.

Гуревич, В. П. (1992) Роль России в исторических судьбах Монголии // VI Международный конгресс монголоведов (Улан-Батор, авг. 1992 г.): в 2 ч. / главн. ред. В. М. Солнцев. М. : Ин-т востоковедения. Ч. 1. 262 с. С. $54-58$.

Грумм-Гржимайло, Г. Е. (1926) Западная Монголия и Урянхайский край Л. : б. и. Т. 2. Вып. 2. Исторический очерк этих стран в связи с историей Средней Азии. 898 с.

Даревская, Е. М. (1994) Сибирь и Монголия: очерки русско-монгольских связей в конце XIX - начале XX вв. Иркутск : Изд-во Иркутского университета. 396 с.

Дацышен, В. Г. (1996) Русско-китайская война. Маньчжурия 1900 г. Часть 1. СПб. : Цитадель. 144 с.

Дацышен, В. Г. (2000) Очерки истории российско-китайской границы во второй половине XIX - начале XX века. Кызыл : Респуб. Типография. 284 с.

Дацышен, В. Г. (2014) Очерки истории Монголии в XIX - первой четверти XX вв. М. : Директ-Медиа. 232 с.

Дацышен, В. Г., Ондар, Г. А. (2003) Саянский узел: Усинско-Урянхайский край и российско-тувинские отношения в 1911-1921 гг. Кызыл : Респ. тип. 284 с

Единархова, Н. Е. (1996) Русские в Монголии: основные этапы и направления деятельности в 1861-1919 гг. // Восток и Россия. Взгляд из Сибири (материалы и тезисы докладов научно-практической конференции16-18 мая 1996 г.) / отв. ред. В. И. Дятлов, В. П. Олтаржевский. Иркутск : Иркутский университет. 416 с. С.59-63.

За три века. Тувинско-русско-монгольско-китайские отношения (1615-1915) (1995) / сост. В. А. Дубровский. Кызыл : Республиканская типография. 84 с.

Златкин, И. Я. (1957) Очерки новой и новейшей истории Монголии. М. : Изд-во Восточной литературы. 300 с.

История отечественного востоковедения с середины XIX века до 1917 года (1997) / сост. А. А. Вигасин и др. М. : Изд. фирма «Восточная литература». 534 с.

История Монгольской Народной Республики (1967) / гл. ред. Е. М. Греков. М. : Изд-во Акад. наук СССР. 532 с.

Кузьмин, С. Л. (2019) Взятие монгольскими повстанцами столицы Барги в 1917 г. // Oriental studies. № 6. С. 2-14. DOI: https://www.doi.org/10.22162/2619-0990-2019-42-2-174-182

Кузьмин, Ю. В. (1995) Урянхай в системе русско-монголо-китайских отношений (1911-1916 гг.) // Взаимоотношения народов России, Сибири и стран Востока: история и современность. Доклады международной научнопрактической конференции. 12-15 окт.1995 г. / отв. ред. Б. Д. Пак. М. ; Иркутск : АРКОМ. 307 с. С. 49-53.

Кузьмин, Ю. В. (1996) «Урянхайский вопрос» в общественной мысли России // Восток и Россия. Взгляд из Сибири (материалы и тезисы докладов научно-практической конференции16-18 мая 1996 г.). отв. ред. В. И. Дятлов, В. П. Олтаржевский. Иркутск : Иркутский университет. 416 с. С. 256-259.

Кузьмин, Ю. В. (1997) Монголия и «Монгольский вопрос» в общественно-политической мысли России (конец XIX - 30-е гг. XX в.). Иркутск : Изд-во Иркут. ун-та. 232 с. 
Кузьмин, Ю. В. (1998) «Монгольский» и «Урянхайский» вопросы в общественно-политической мысли России (конец XIX - 30-е годы XX в.) : дисс.... д-ра ист. н. Иркутск. 418 с.

Лиштованный, Е. И. (1998) Россия и Монголия в ХХ в.: Региональный опыт взаимоотношений. На материалах Восточной Сибири : дисс. ... д-ра ист. н. Иркутск. 430 с.

Лузянин, С. Г. (1996) Монголия между Россией и КНР: исторический опыт и современные реалии // Восток. № 6. C. $110-113$.

Лузянин, С. Г. (1997) Россия - Монголия - Китай: Внешнеполитические отношения в 1911-1946 гг. : дисс. ... д-ра ист. н. М. 434 с.

Лузянин, С. Г. (2000) Россия-Монголия-Китай в первой половине политических взаимоотношений в 1911-1946 гг. М. : Изд-во МГИМО. 268 с.

Лхамсурэн, Б. (1995) Монголын гадаадорчин, торийнт усгаартогтнол [Внешняя среда и государственная независимость Монголии]. Улаанбаатар: Ин-т истории АН. 126 с. (На монг. яз.)

Мясников, В. С. (1997) Договорными статьями утвердили (дипломатическая история русско-китайской границы XVII - XX вв.). Хабаровск : б. и. 543 с.

Мясников, В. С. (2002) Восток-Запад-Монголия: историко-литературный альманах /отв. ред. В.С. Мясников. М. : Восточная литература. 358 с.

Ондар, Г. А. (2000) Российско-тувинские отношения в 1911-1921 гг. : дисс.... канд. ист. н. Кызыл. 194 с.

Политическая история Монголии (1921-1940) (1999) / сост. С. К. Рощин. М. : ИВ РАН. 325 с.

Российские монголоведы (XVIII - начало XX в.) (1997) / сост. и отв. ред. Ш. Б. Чимитдоржиев. Улан-Удэ : Изд-во Бурятского научного центра. 163 с.

Слесарчук, Г. И. (сост.) (1996) Русско-монгольские отношения 1654-1685. Сборник документов / отв. ред. Н. Ф. Демидова. М. : Восточная литература РАН. 560 с.

Тарасов, А. П. (2013) Исторические судьбы Барги в Забайкалье // Азия и Африка сегодня. № 4. С. $50-55$.

Улымжиев, Д. Б. (1997) Монголоведение в России во второй половине X1X - начале XX в. Петербургская школа монголоведения. Улан-Удэ : Изд-во Бурят. гос. ун-та. 216 с.

Урянхай. Тыва Дептер (2007). Антология научной и просветительской мысли о древней тувинской земле и её насельниках, об Урянхае - Танну-Туве, урянхайцах - тувинцах, о древностях Тувы (II тысячелетие до н. э. - первая половина XX в.) : в 7 т. / сост. С. К. Шойгу. М. : Слово/Slovo. T. 5.733 с.

Ученые записки. Серия историческая (1995) / ред. коллегия Ч. М. Доржу и др. Вып. XVIII. Кызыл : б/и. 201 с.

Шурхуу, Д. (2001) Урянхайский вопрос в монголо-российских отношениях в первой четверти XX века // Россия и Монголия: новый взгляд на историю взаимоотношений в XX веке / отв. ред. : Н. Алтанцэцэг и др. М. : ИВ РАН. 276 с. С. $97-117$.

沙俄侵略中国的 史 [История агрессии царской России против Китая] (1986). Шаньхай, исторический факультет Фуданьского университета. 532 с. (На кит. яз.)

Дата поступления: 09.07.2021 2.

\section{REFERENCES}

Batsaikhan, O. (2011) Mongolyn sü̈̈lchiin ezen khaan VIII Bogd Zhavzandamba [The last Emperor of Mongolia VIII Bogd Jauzandamba-Hutukta]. Ulaanbaatar, Admon. 708 p. (In Mong.)

Belov, E. A. (1956) Revoliutsiia 1911-1913 gg. v Kitae [The 1911-1913 Revolution in China]: Diss.... Candidate of History. Moscow. 318 p. (In Russ.)

Belov, E. A. (1992) Dala-lama Tseren Chimid i tsarskaia diplomatiia [The Dala-Lama Tseren Chimid and Tsarist diplomacy]. In: VI Mezhdunarodnyi kongress mongolovedov (Ulan-Bator, avg. 1992 g.) [6th International Congress of Mongol Studies (Ulaanbaatar, Aug. 1992)] / ed. by V. M. Solntsev. Moscow, In-t vostokovedeniia. 262 p. Pp. 2-14. (In Russ.)

Belov, E. A. (1993a) Barginskii vopros po materialam russkikh arkhivov [The Barga question based on the materials from Russian archives]. Vostok, no. 1, pp. 170-178. (In Russ.)

Belov, E. A. (1993b) Russko-kitaiskie otnosheniia v 1911-1915 gg. [Russian-Chinese relations in 1911-1915]: Diss. ... Doctor of History. Moscow. 546 p. (In Russ.)

Belov, E. A. (1994a) Reaktsiia v Kitae na russko-mongol'skoe soglashenie 1912 g. [The reaction in China to the RussianMongolian agreement of 1912]. Problemy Dal'nego Vostoka, no. 4, pp. 108-118. (In Russ.) 
Belov, E. A. (1994b) Kak voznikli troistvennye russko-kitaisko-mongol'skie peregovory v Kiakhte v 1914 g. [How the triple Russian-Chinese-Mongolian negotiations commenced in Kyakhta in 1914]. In: Kitaiskaia traditsionnaia kul'tura i problemy modernizatsii [Chinese traditional culture and problems of modernization]. Abstracts of the $5^{\text {th }}$ International Research Conference "China. Chinese civilization and the world”. Moscow, October 12-14. / ed. by R. M. Aslanov. Moscow, IDV RAN. 184 p. Pp. 175-181. (In Russ.)

Belov, E. A. (1995) Problema Uriankhaiskogo kraia v russko-kitaisko-mongol'skikh otnosheniiakh 1911-1914 gg. [The problem of the Uriankhai Territory in the Russian-Chinese-Mongolian relations, 1911-1914]. Vostok, no. 1, pp. 58-67. (In Russ.)

Belov, E. A. (1996) Poslednii «zhivoi Bog mongolov» [The last “living God of the Mongols”]. Aziia i Afrika segodnia, no. 3, pp. 2-17. (In Russ.)

Belov, E. A. (1997) Rossiia i Kitai v nachale XX veka (russko-kitaiskie protivorechiia v 1911-1915 gg.) [Russia and China at the beginning of the twentieth century: Russian-Chinese contradictions, 1911-1915]. Moscow, IV RAN. 314 p. (In Russ.)

Belov, E. A. (1999) Rossiia i Mongoliia (1911-1919) [Russia and Mongolia, 1911-1919]. Moscow, IV RAN. 235 s. (In Russ.)

Belov, E. A. (2001) Kratkaia istoriia Sin'khaiskoi revoliutsii. 1911-1913 [A brief history of the Xinhai Revolution. 1911-1913]. Moscow, Vostochnaia literatura RAN. 160 p. (In Russ.)

Belov, E. A. (2003) Baron Ungern fon Shternberg: Biografiia. Ideologiia. Voennye pokhody. 1920-1921 gg. [Baron Ungern von Sternberg: Biography. Ideology. Military campaigns. 1920-1921]. Moscow, Agraf. 240 p. (In Russ.)

Belov, E. A. (2007) Bor'ba za Uriankhaiskii krai v 1915-1919 godakh [The struggle for the Uriankhai Territory in 1915-1919]. In: Uriankhai. Tyva Depter. Antologiia nauchnoi i prosvetitel'skoi mysli o drevnei tuvinskoi zemle i ee nasel'nikakh, ob Uriankhae - Tannu-Tuve, uriankhaitsakh - tuvintsakh, o drevnostiakh Tuvy (II tysiacheletie do n. e. - pervaia polovina $X X$ v.) [Uriankhai. Tyva Depter. An anthology of research and educational thought about the ancient Tuvan land and its inhabitants, about Uriankhai-Tannu-Tuva, Uriankhai-Tuvans, and about the antiquities of Tuva ( $2^{\text {nd }}$ millennium BC to the first half of the $20^{\text {th }}$ century)]: in 7 vols. / comp. by S. K. Shoigu. Moscow, Slovo/Slovo. Vol. 5.733 p. Pp. 496-519. (In Russ.)

Bibliograficheskii slovar' otechestvennykh vostokovedov s 1917 goda [A bibliographical dictionary of Russian orientalists since 1917] (1995) : in 2 books / comp. by S. D. Miliband. $2^{\text {nd }}$ ed. Moscow, Nauka. Book I. A-L. 702 p. (In Russ.)

Bumbazhai, A. K. (1999) Rossiia i Tuva: problema stanovleniia sviazei v kontse XIX - nachale XX vekov [Russia and Tuva: shaping their relations in the late $19^{\text {th }}$ and early $20^{\text {th }}$ centuries]: Abstract of Diss.... Candidate of History. Moscow. 28 p. (In Russ.)

Vasilenko, V. A. (2014) Na puti k protektoratu (otnosheniia pravitel'stva imperskoi Rossii s Kitaem i Mongoliei po voprosam ustanovleniia politicheskogo vliianiia $v$ Tuve vo vtoroi polovine XIX v. - $1914 \mathrm{~g}$.) [On the way to the protectorate: the relations between the government of Imperial Russia and China and Mongolia on the establishing political influence over Tuva, the second half of the 19 ${ }^{\text {th }}$ century to 1914)]. Irkutsk, Irkutsk State University Press. 223 p. (In Russ.)

Voskresenskii, A. D. (1997) Rossiia i Kitai: teoriia i istoriia mezhgosudarstvennykh otnoshenii [Russia and China: theory and history of interstate relations]. Moscow, Mosk. Obshchestv. Nauchn. fond. 405 p. (In Russ.)

Rossiia i Vostok: vzgliad iz Sibiri [Russia and the East: a view from Siberia] (1998): Materials and proceedings of $11^{\text {th }}$ Research Conference. Irkutsk, May 13-16 / editorial board: V. I. Diatlov (ed.) et al. Irkutsk, Irkutsk State University Press. Vol. 2. 302 p. (In Russ.)

Graivoronskii, V. V. (1996) Mongoliia: izmeneniia v strukture semeinykh biudzhetov sel'skogo naseleniia pri perekhode ot sotsialisticheskoi modeli razvitiia $k$ rynochnoi [Mongolia: changes in the structure of family budgets of the rural population during the transition from the socialist model of development to the market one]. Moscow, In-t vostokovedeniia RAN. 64 p. (In Russ.)

Gol'man, M. I. (1998) Izuchenie istorii Mongolii na Zapade, XIII - seredina XX v. [Studying the History of Mongolia in the West, XIII - mid-XX century]. Moscow, Nauka. 218 p. (In Russ.)

Gurevich, V. P. (1992) Rol' Rossii v istoricheskikh sud'bakh Mongolii [The role of Russia in the historical destinies of Mongolia]. In: VI Mezhdunarodnyi kongress mongolovedov (Ulan-Bator, avg. 1992 g.) [VI International Congress of Mongolian Studies (Ulaanbaatar, Aug. 1992)]: in 2 parts / ed. by V. M. Solntsev. Moscow, In-t vostokovedeniia. Part 1. 262 p. Pp. 54-58. (In Russ.)

Grum-Grzhimailo, G. E. (1926) Zapadnaya Mongoliya i Uryanhaiskii krai [Western Mongolia and the Uriankhai Territory]. Vol. 3. Part 1. An anthropological and ethnographical sketch of these countries by G. Grum-Grzhimailo. Leningrad, State (Russian) Geographical Society. 412 p. (In Russ.).

Darevskaia, E. M. (1994) Sibir' i Mongoliia: ocherki russko-mongol'skikh sviazei v kontse XIX - nachale XX vv. [Siberia and Mongolia: essays on Russian-Mongolian relations in the late $19^{\text {th }}$ - early $20^{\text {th }}$ century]. Irkutsk, Irkutsk State University Press. 396 p. (In Russ.) 
Datsyshen, V. G. (1996) Russko-kitaiskaia voina. Man'chzhuriia 1900 g. Chast' 1 [The Russian-Chinese War, Manchuria 1900: Part 1]. St. Petersburg, Tsitadel'. 144 p. (In Russ.)

Datsyshen, V. G. (2000) Ocherki istorii rossiisko-kitaiskoi granitsy vo vtoroi polovine XIX - nachale XX veka [Essays on the history of the Russian-Chinese border in the second half of the $19^{\text {th }}$ and early $20^{\text {th }}$ century]. Kyzyl, Respub. Tipografiia. $284 \mathrm{p}$. (In Russ.)

Datsyshen, V. G. and Ondar, G. A. (2003) Saianskii uzel: Usinsko-Uriankhaiskii krai i rossiisko-tuvinskie otnosheniia v 1911-1921 gg. [The Sayan Knot: the Usinsk-Uriankhai Territory and Russian-Tuvan relations in 1911-1921]. Kyzyl, Resp. tip. 284 p. (In Russ.)

Datsyshen, V. G. (2014) Ocherki istorii Mongolii v XIX - pervoi chetverti XX vv. [Essays on the history of Mongolia in the $19^{\text {th }}$ and first quarter of the $20^{\text {th }}$ century]. Moscow, Direkt-Media. 232 p. (In Russ.)

Edinarkhova, N. E. (1996) Russkie v Mongolii: osnovnye etapy i napravleniia deiatel'nosti v 1861-1919 gg. [Russians in Mongolia: main stages and aspects of activity, 1861-1919]. In: Vostok i Rossiia. Vzgliad iz Sibiri [The East and Russia. A view from Siberia]. Materials and abstracts of reports of the scientific and practical conference May 16-18, 1996 / ed. by V. I. Diatlov and V. P. Oltarzhevskii. Irkutsk, Irkutsk State University Press. 416 p. Pp. 59-63. (In Russ.)

Za tri veka. Tuvinsko-russkie-mongol'skie-kitaiskie otnosheniia (1616-1915 gg.) [Over three centuries. Tuva-RussianMongolian-Chinese relations (1616-1915)] (1995): a collection of archival documents / comp. by V. A. Dubrovskii. Kyzyl, s. n. 84 p. (In Russ.).

Zlatkin, I. Ya. (1957) Ocherki novoi i noveishei istorii Mongolii [Essays on the modern history of Mongolia]. Moscow, Izd-vo Vostochnoi literatury. 300 p. (In Russ.)

Istoriia otechestvennogo vostokovedeniia s serediny XIX veka do 1917 goda [The history of Russian Oriental studies from the middle of the $1^{\text {th }}$ century to 1917] (1997) / comp. by A. A. Vigasin et al. Moscow, Vostochnaia literatura. 534 p. (In Russ.)

Istoriia Mongol'skoi Narodnoi Respubliki [A History of the Mongolian People's Republic] (1967) / ed. by E. M. Grekov. Moscow, Izd-vo Akad. nauk SSSR. 532 p. (In Russ.)

Kuz'min, S. L. (2019) Vziatie mongol'skimi povstantsami stolitsy Bargi v 1917 g. [The Conquest of the Capital Town of Barga (Hulunbuir) by Mongolian Guerillas]. Oriental studies, no. 6, pp. 2-14.(In Russ.). DOI: https://doi.org/10.22162/26190990-2019-42-2-174-182

Kuz'min, Yu. V. (1995) Uriankhai v sisteme russko-mongolo-kitaiskikh otnoshenii (1911-1916 gg.) [Uriankhai in the system of Russian-Mongolian-Chinese relations, 1911-1916]. In: Vzaimootnosheniia narodov Rossii, Sibiri i stran Vostoka: istoriia i sovremennost' [Relations between the peoples of Russia, Siberia and the countries of the East: history and modernity]. Proceedings of the international research conference. October 12-15, 1995 / ed. by B. D. Pak. Moscow, Irkutsk, ARKOM. 307 p. Pp. 49-53. (In Russ.)

Kuz'min, Yu. V. (1996) «Uriankhaiskii vopros» v obshchestvennoi mysli Rossii [“The Uriankhai question” in the public thought of Russia]. In: Vostok i Rossiia. Vzgliad iz Sibiri [East and Russia. A view from Siberia]. Materials and abstracts of reports of the scientific and practical conference May 16-18, 1996 / ed. by V. I. Diatlov and V. P. Oltarzhevskii. Irkutsk, Irkutsk State University Press. 416 p. Pp. 256-259. (In Russ.)

Kuz'min, Yu. V. (1997) Mongoliia i «Mongol'skii vopros»v obshchestvenno-politicheskoi mysli Rossii (konets XIX - 30-e gg. XX v.) [Mongolia and the "Mongolian question" in the socio-political thought of Russia, late $19^{\text {th }}$ century to 1930s]. Irkutsk, Irkutsk State University Press. 232 p. (In Russ.)

Kuz'min, Yu. V. (1998) «Mongol'skii» $i$ «Uriankhaiskii» voprosy v obshchestvenno-politicheskoi mysli Rossii (konets XIX - 30-e gody XX v.) ["Mongolian" and "Uriankhai" issues in the socio-political thought of Russia, late 19" century to 1930s]: Diss.... Doctor of History. Irkutsk. 418 p. (In Russ.)

Lishtovannyi, E. I. (1998) Rossiia i Mongoliia v XX v.: Regional'nyi opyt vzaimootnoshenii. Na materialakh Vostochnoi Sibiri [Russia and Mongolia in the twentieth century: Regional experience of relations. The case of Eastern Siberia]: Diss. ... Doctor of History. Irkutsk. 430 p. (In Russ.)

Luzianin, S. G. (1996) Mongoliia mezhdu Rossiei i KNR: istoricheskii opyt i sovremennye realii [Mongolia between Russia and China: historical experience and modern realities]. Vostok, no. 6, pp. 110-113. (In Russ.)

Luzianin, S. G. (1997) Rossiia - Mongoliia - Kitai: Vneshnepoliticheskie otnosheniia v 1911-1946 gg. [Russia-MongoliaChina: Foreign affairs in 1911-1946] : Diss.... Doctor of History. Moscow. 434 p. (In Russ.)

Luzianin, S. G. (2000) Rossiia-Mongoliia-Kitai v pervoi polovine politicheskikh vzaimootnoshenii v 1911-1946 gg. [RussiaMongolia-China in the earlier half of their political relations: 1911-1946]. Moscow, Izd-vo MGIMO. 268 p. (In Russ.)

Lkhamsuren, B. (1995) Mongolyn gadaadorchin, toriint usgaartogtnol [External environment and state independence of Mongolia]. Ulaanbaatar, In-t istorii AN. 126 p. (In Mong.) 
Miasnikov, V. S. (1997) Dogovornymi stat'iami utverdili (diplomaticheskaia istoriia russko-kitaiskoi granitsy XVII $X X v v$.) [Approved by the articles of the treaty: A diplomatic history of the Russian-Chinese border in the $17^{\text {th }}-20^{\text {th }}$ centuries]. Khabarovsk, s. n. 543 p. (In Russ.)

Miasnikov, V. S. (2002) Vostok-Zapad-Mongoliia: istoriko-literaturnyi al'manakh [East-West-Mongolia: a historical and literary almanac] / ed. by V. S. Miasnikov. Moscow, Vostochnaia literatura. 358 p. (In Russ.)

Ondar, G. A. (2000) Rossiisko-tuvinskie otnosheniia v 1911-1921 gg. [Russian-Tuvan relations in 1911-1921] : Diss. ... Candidate of History. Kyzyl. 194 p. (In Russ.)

Politicheskaia istoriia Mongolii (1921-1940) [A political history of Mongolia (1921-1940)] (1999) / comp. by S. K. Roshchin. Moscow, IV RAN. 325 p. (In Russ.)

Rossiiskie mongolovedy (XVIII - nachalo XX v.) [Russian scholars in Mongol studies, 18 ${ }^{\text {th }}$ to early XX century] (1997) / comp. and ed. by Sh. B. Chimitdorzhiev. Ulan-Ude, Publishing house of the Buryat Research Center. 163 p. (In Russ.)

Slesarchuk, G. I. (sost.) (1996) Russko-mongol'skie otnosheniia 1654-1685. Sbornik dokumentov [Russian-Mongolian relations 1654-1685: A collection of documents] / ed. by N. F. Demidova. Moscow, Vostochnaia literatura RAN. 560 p. (In Russ.)

Tarasov, A. P. (2013) Istoricheskie sud'by Bargi v Zabaikal'e [The historical fate of the Barga Mongols in Transbaikalia]. Aziia i Afrika segodnia, no. 4, pp. 50-55. (In Russ.)

Ulymzhiev, D. B. (1997) Mongolovedenie v Rossii vo vtoroi polovine XIX - nachale XX v. Peterburgskaia shkola mongolovedeniia [Mongolian studies in Russia in the second half of the $19^{\text {th }}-$ early $20^{\text {th }}$ century]. Ulan-Ude, Publishing House of the Buryat State University. 216 p. (In Russ.)

Uriankhai. Tyva depter (2007) : Antologiia nauchnoi i prosvetitel'skoi mysli o drevnei tuvinskoi zemle i ee nasel'nikakh, ob Uriankhae - Tannu-Tuve, uriankhaitsakh - tuvintsakh, o drevnostiakh Tuvy [Uriankhai: The Tuva Notebook: An anthology of research and educational thought on the ancient land of Tuva and its population, on Uriankhai - Tannu-Tuva, Uriankhaians Tuvan people, and on the antiquities of Tuva], in 7 vols. Comp. by S. K. Shoigu. Moscow, Slovo. Vol. 5: Uriankhaiskii krai: ot Uriankhaia k Tannu-Tuve [Uriankhai territory: from Uriankhai to Tannu-Tuva (late XIX - first half of XX century)]. 736 p. (In Russ.)

Uchenye zapiski. Seriia istoricheskaia [Proceedings. Series History series] (1995) / editorial board: Ch. M. Dorzhu et al. Vol. XVIII. Kyzyl, s. n. 201 p. (In Russ.)

Shurkhuu, D. (2001) Uriankhaiskii vopros v mongolo-rossiiskikh otnosheniiakh v pervoi chetverti XX veka [The Uriankhai question in Mongolian-Russian relations in the first quarter of the twentieth century]. In: Rossiia i Mongoliia: novyi vzgliad na istoriiu vzaimootnoshenii v XX veke [Russia and Mongolia: a new look at the history of relations in the XX century] / ed. by N. Altantsetseg et al. Moscow, IV RAN. Pp. 97-117. (In Russ.)

沙俄侵略中国的 史 [The History of the aggression of Tsarist Russia against China] (1986). Shan'khai, istoricheskii fakul'tet Fudan'skogo universiteta. 532 p. (In Chinese).

Submission date: 09.07.2021. 